\title{
Chemical intolerance: involvement of brain function and networks after exposure to extrinsic stimuli perceived as hazardous
}

Kenichi Azuma ${ }^{1,2^{*}}$ D, Iwao Uchiyama ${ }^{2,3}$, Mari Tanigawa ${ }^{3,4}$, Ikuko Bamba ${ }^{5}$, Michiyo Azuma ${ }^{6}$, Hirohisa Takano ${ }^{7}$, Toshikazu Yoshikawa ${ }^{2}$ and Kou Sakabe ${ }^{8}$

\begin{abstract}
Background: Chemical intolerance $(\mathrm{Cl})$ is a chronic condition characterized by recurring and severe symptoms triggered by exposure to low levels of odorous or pungent substances. The etiology of $\mathrm{Cl}$ has been a controversial subject for a long time. The aim of this review is to summarize findings on the neurological processing of sensory information during and after exposure to low levels of odorous or pungent substances in individuals with $\mathrm{Cl}$, focusing on the brain function and networks.

Methods: Scientific studies on Cl published between 2000 and 2019 in academic peer-reviewed journals were systematically searched using medical and scientific literature databases. Only peer-reviewed articles reporting original research from experimental human studies directly associated with $\mathrm{Cl}$, and involving related neurological responses or brain imaging after exposure to odorous or pungent substances (i.e., in chemical provocation tests), were considered.

Results: Forty-seven studies were found to be eligible for a full-text review. Twenty-three studies met the selection criteria and were included in this review. Evidence indicated that differences between subjects with $\mathrm{Cl}$ and healthy controls were observed by brain imaging during and after exposure to odorous or pungent substances. Differences in brain imaging were also observed between initial exposure and after exposure to these substances. Neurological processing of sensory information after exposure to extrinsic stimuli in the limbic system and related cortices were altered in subjects with $\mathrm{Cl}$. A previous documentable exposure event was likely to be involved in this alteration.

Conclusions: This review documents consistent evidence for the altered neurological processing of sensory information in individuals with $\mathrm{Cl}$. Further neurophysiological research exploring the processing of extrinsic stimuli and cognition of sensation through the limbic system and related cortices in $\mathrm{Cl}$, and the appearance of symptoms in individuals with $\mathrm{Cl}$, are required.
\end{abstract}

Keywords: Brain imaging, Chemical intolerance, Exposure event, Limbic system, Multiple chemical sensitivity, Odor processing, Prefrontal cortex, Psychosomatic symptoms, Sensory disruption, Susceptibility

\footnotetext{
* Correspondence: kenazuma@med.kindai.ac.jp

${ }^{1}$ Department of Environmental Medicine and Behavioral Science, Kindai University Faculty of Medicine, 377-2 Ohnohigashi, Osakasayama, Osaka 589-8511, Japan

${ }^{2}$ Sick-house Medical Science Laboratory, Division of Basic Research, Louis

Pasteur Center for Medical Research, Kyoto 606-8225, Japan

Full list of author information is available at the end of the article
}

(c) The Author(s). 2019 Open Access This article is distributed under the terms of the Creative Commons Attribution 4.0 International License (http://creativecommons.org/licenses/by/4.0/), which permits unrestricted use, distribution, and reproduction in any medium, provided you give appropriate credit to the original author(s) and the source, provide a link to the Creative Commons license, and indicate if changes were made. The Creative Commons Public Domain Dedication waiver (http://creativecommons.org/publicdomain/zero/1.0/) applies to the data made available in this article, unless otherwise stated. 


\section{Background}

Intolerance to odorous or pungent substances, known as chemical intolerance $(\mathrm{CI})$, is a widespread occupational and public health problem and has been frequently reported in industrialized countries [1-3]. CI is a chronic acquired disorder characterized by nonspecific and recurrent symptoms in multiple organ systems associated with exposure to low levels of odorous or pungent substances (e.g., fragranced consumer products, cleaning products, combustion products, petroleum products, perfumes, softeners, new furniture, new newspapers, environmental tobacco smoke, building materials, organic solvents, pesticides, and car exhaust) at concentrations usually tolerated by most of the population [2, 4-6].

The type and severity of symptoms reported in response to exposure are highly variable. A number of symptoms involve the central nervous system (CNS) (e.g., headaches, dizziness, fatigue, irritability, cognitive deficit, anxiety, dyspnea, and difficulty concentrating) and are often combined with nonspecific symptoms from other organ systems, including the skin, mucosa/respiratory tract, musculoskeletal system, cardiovascular system, and gastrointestinal tract [2, 5, 7-10]. Between 8 and 33\% of people in various populations consider themselves unusually sensitive to odorous or pungent substances, with the variability in prevalence depending largely on a wide variety of definitions and severity [3, 8, 11-22].

Severe CI is often referred to as multiple chemical sensitivity (MCS) [1, 2, 4, 6, 23]. Some groups prefer the name idiopathic environmental intolerance (IEI) to avoid confusion in diagnosis and etiology associated with the terms CI and MCS [24-28], because these terms imply unsupported judgments on causation, do not refer to a clinically defined disease, and are not based on accepted theories of underlying mechanisms or validated clinical criteria for diagnosis [29].

Thus, although the prevalence of nonclinical occurrence in the population is relatively high, the mechanisms behind CI and its diagnosis and etiology remain controversial and understudied. Most definitions are almost entirely qualitative, depending on subjective reports of symptoms and environmental exposure from patients and clinicians $[1,9,30,31]$. However, various theories suggest that alterations in chemical sensory transduction and neural processing, rather than toxic processes, serve as key mechanisms of CI. Related experimental studies of subjects with CI have recently been reported [1, 31-37] and increased after the MCS 1999 consensus, which proposed consensus criteria for the definition of MCS [30]. In this article, we review findings on the neurological processing of sensory information in exposure to low levels of odorous or pungent substances in individuals with CI. In particular, we look at brain function and network activity after exposure to these substances.

\section{Methods}

An online literature search was conducted across major electronic databases, including PubMed and Google Scholar, between January 1, 2000, and July 8, 2019. PubMed was primarily used to identify potential articles that met the search criteria, and others were used as complementary databases. The following key words were used as search criteria: "chemical intolerance" OR "chemical sensitivity." A total of 871 articles were retrieved. The retrieved articles were reviewed by a reviewer (KA) in two stages: screening of titles and abstracts, followed by a full-text review. Additional articles were identified based on prior knowledge (e.g., documents or reports of international or national organizations) and by manual screening of the bibliographies of retrieved articles. After a thorough review of titles and abstracts, 47 studies were found to be eligible for a full-text review. Of these, 23 met our selection criteria and were included in this review (Table 1). Specifically, only peer-reviewed articles reporting original research from experimental human studies directly associated with $\mathrm{CI}$ or MCS, including IEI due to chemical exposure and involving related neurological responses or brain imaging after exposure to odorous or pungent substances (i.e., chemical provocation tests) were considered. Studies focusing on electromagnetic fields and noise, and not chemical provocation, were excluded.

Exposure event and human response to external stressors Before describing the results of our review of neurological responses, we describe the primary characteristics of $\mathrm{CI}$ and the principal concept on human responses to external environmental factors when considering CI status.

\section{Exposure episodes in the onset of $\mathrm{Cl}$}

CI occurs when individuals are first sensitized via an initial exposure to a certain amount of chemical or repeated exposure to small amounts of chemical (i.e., documentable exposure). On re-exposure, individuals become increasingly sensitized; often, the effects spread, and individuals become sensitized to several additional chemicals [4]. In clinical practice, patients with $\mathrm{CI}$ or MCS often report some kind of exposure event that leads to an onset of CI or MCS. Patients with MCS diagnosed in our outpatient department (officially, Outpatient Department of Sick House Syndrome, Hyakumanben Clinic, Kyoto, Japan) experienced episodes of initial exposure to chemicals that first triggered symptoms. For example, they reported exposure to organic solvents, use of pesticides or incense in the workplace, odors from pesticides or exhaust from nearby diesel machines, fragrance from a neighbor, evaporated pesticides used indoors, or chemical exposure after renovation of a house or moving into a newly built home. Other patients had episodes of 
Table 1 Summary of experimental human studies associated with $\mathrm{Cl}$ and related neurological responses or brain imaging in chemical provocation tests

\begin{tabular}{|c|c|c|c|c|c|c|}
\hline $\begin{array}{l}\text { Study, year with } \\
\text { reference }\end{array}$ & Type of analysis & $\begin{array}{l}\text { Subjects (Cl or } \\
\text { MCS/control) }\end{array}$ & Substances & $\begin{array}{l}\text { Exposure } \\
\text { time }\end{array}$ & Measurement & Findings \\
\hline $\begin{array}{l}\text { Alessandrini et al. } \\
2016 \text { [38] }\end{array}$ & $\begin{array}{l}\text { PET with }{ }^{18} \mathrm{FDG} \\
\text { uptake }\end{array}$ & $26 / 11$ & Saline, vanillin & $9 \min$ & $\begin{array}{l}\text { After } 24 \text { min } \\
\text { of exposure }\end{array}$ & $\begin{array}{l}\text { Different subcortical olfactory } \\
\text { processing and an increased } \\
\text { responsiveness in the central } \\
\text { nervous system and olfactory } \\
\text { center }\end{array}$ \\
\hline $\begin{array}{l}\text { Andersson et al. } \\
2009 \text { [39] }\end{array}$ & EEG, EOG & $21 / 17$ & $\begin{array}{l}\mathrm{CO}_{2} \text {, amyl acetate (banana } \\
\text { smelling), sound }\end{array}$ & $\begin{array}{l}200 \text { ms } \\
\text { repetition, } \\
72 \text { stimuli } \\
\text { during } 1.5 \\
\text { h }\end{array}$ & During task & $\begin{array}{l}\text { Attention bias and enhanced } \\
\text { sensitization, and alterations in } \\
\text { central, cognitive responses to } \\
\text { chemical exposure }\end{array}$ \\
\hline $\begin{array}{l}\text { Andersson et al. } \\
2014 \text { [40] }\end{array}$ & fMRI & $25 / 26$ & $\begin{array}{l}\mathrm{CO}_{2} \text {, isoamyl acetate } \\
\text { (banana smelling, below } \\
\text { irritation threshold) }\end{array}$ & $\begin{array}{l}20 \\
\text { repetitions } \\
\text { of } 30 \mathrm{~s}\end{array}$ & During task & $\begin{array}{l}\text { Not characterized by } \\
\text { hyperresponsiveness in sensory } \\
\text { areas and interpreted as a limbic } \\
\text { hyperactivity and speculatively as } \\
\text { an inability to inhibit salient } \\
\text { external stimuli }\end{array}$ \\
\hline $\begin{array}{l}\text { Andersson et al. } \\
2016 \text { [23] }\end{array}$ & $\begin{array}{l}\text { Autonomic } \\
\text { recordings }\end{array}$ & $18 / 18$ & $\begin{array}{l}\text { n-Butanol (below irritation } \\
\text { threshold) }\end{array}$ & $42 \min$ & During task & $\begin{array}{l}\text { Altered autonomic responses } \\
\text { (higher pulse rate and lower pulse } \\
\text { rate variability) and chemosensory } \\
\text { perception during chemical } \\
\text { exposure }\end{array}$ \\
\hline $\begin{array}{l}\text { Andersson et al. } \\
2017 \text { [41] }\end{array}$ & fMRI & $\begin{array}{l}14 \text { olfactory } \\
\text { sensitizers, } 20 \\
\text { intermediate, } \\
\text { and } 15 \\
\text { habituaters }\end{array}$ & $\begin{array}{l}\mathrm{CO}_{2} \text {, isoamyl acetate } \\
\text { (banana smelling, below } \\
\text { irritation threshold) }\end{array}$ & $\begin{array}{l}20 \\
\text { repetitions } \\
\text { of } 30 \mathrm{~s}\end{array}$ & During task & $\begin{array}{l}\text { In reanalysis of Andersson et al. } \\
\text { (2014) [40], greater reactions in } \\
\text { regions relevant for pain and } \\
\text { saliency detection, and olfactory } \\
\text { projection areas (olfactory region of } \\
\text { the orbitofrontal cortex) }\end{array}$ \\
\hline $\begin{array}{l}\text { Azuma et al. } \\
2013 \text { [32] }\end{array}$ & fNIRS & $12 / 11$ & $\begin{array}{l}\text { Odorants (mandarin } \\
\text { orange, perfume, Japanese } \\
\text { cypress, and menthol) }\end{array}$ & $10 \mathrm{~s}$ & $\begin{array}{l}\text { During } \\
\text { exposure }\end{array}$ & $\begin{array}{l}\text { Activation in the prefrontal cortex } \\
\text { during exposure. Poorer autonomic } \\
\text { perception and negative affectivity. } \\
\text { Altered prefrontal information } \\
\text { processing associated with odor } \\
\text { processing and memory and } \\
\text { cognition processes }\end{array}$ \\
\hline $\begin{array}{l}\text { Azuma et al. } \\
2015 \text { [33] }\end{array}$ & fNIRS & $6 / 6$ & $\begin{array}{l}\text { Odorants (mandarin } \\
\text { orange, perfume, Japanese } \\
\text { cypress, and menthol) }\end{array}$ & $10 \mathrm{~s}$ & $\begin{array}{l}\text { After } \\
\text { exposure }\end{array}$ & $\begin{array}{l}\text { Activation in the orbitofrontal } \\
\text { cortex after exposure. Altered } \\
\text { prefrontal information processing } \\
\text { associated with odor processing } \\
\text { and memory and cognition } \\
\text { processes }\end{array}$ \\
\hline $\begin{array}{l}\text { Azuma et al. } \\
2016[34]\end{array}$ & fNIRS & $10 / 6$ & Odorants (sweet and fecal) & $10 \mathrm{~s}$ & $\begin{array}{l}\text { During and } \\
\text { after } \\
\text { exposure }\end{array}$ & $\begin{array}{l}\text { Activation in the prefrontal cortex } \\
\text { and orbitofrontal cortex. Altered } \\
\text { prefrontal information processing } \\
\text { associated with odor processing } \\
\text { and memory and cognition } \\
\text { processes }\end{array}$ \\
\hline $\begin{array}{l}\text { Bornschein et al. } \\
2008 \text { [42] }\end{array}$ & $\begin{array}{l}\text { Serum cortisol, } \\
\text { cognitive } \\
\text { performance }\end{array}$ & $20 / 17$ & $\begin{array}{l}\text { Solvent mixture of } \\
\text { hydrocarbons (below odor } \\
\text { threshold) }\end{array}$ & $\begin{array}{l}3 \\
\text { repetitions } \\
\text { of } 15 \mathrm{~min}\end{array}$ & $\begin{array}{l}\text { Before and } \\
\text { after the } \\
\text { exposure }\end{array}$ & No differences \\
\hline $\begin{array}{l}\text { Chiaravalloti } \\
\text { et al. } 2015 \text { [43] }\end{array}$ & $\begin{array}{l}\text { PET with }{ }^{18} \mathrm{FDG} \\
\text { uptake }\end{array}$ & $26 / 11$ & Saline, vanillin & $9 \min$ & $\begin{array}{l}\text { After } 24 \text { min } \\
\text { of exposure }\end{array}$ & $\begin{array}{l}\text { Different cortical olfactory } \\
\text { processing with deactivation that } \\
\text { mainly involves the frontal cortex } \\
\text { and by active recruitment of the } \\
\text { left inferior temporal gyrus }\end{array}$ \\
\hline $\begin{array}{l}\text { Claeson et al. } \\
2017 \text { [44] }\end{array}$ & $\begin{array}{l}\text { SCA, sensory } \\
\text { irritation }\end{array}$ & $18 / 19$ & Acrolein, heptan & $60 \mathrm{~min}$ & $\begin{array}{l}\text { Before } \\
\text { exposure, } \\
\text { after and } 24 \\
\text { h } \\
\text { postexposure }\end{array}$ & $\begin{array}{l}\text { No differences in SCA, greater } \\
\text { sensory irritation, suggesting altered } \\
\text { trigeminal reactivity }\end{array}$ \\
\hline
\end{tabular}

Claeson et al. Serum oxylipins 18/19 Acrolein, heptan $\quad 60 \mathrm{~min} \quad$ Before $\quad$ No differences 
Table 1 Summary of experimental human studies associated with $\mathrm{Cl}$ and related neurological responses or brain imaging in chemical provocation tests (Continued)

\begin{tabular}{|c|c|c|c|c|c|c|}
\hline $\begin{array}{l}\text { Study, year with } \\
\text { reference }\end{array}$ & Type of analysis & $\begin{array}{l}\text { Subjects (Cl or } \\
\text { MCS/control) }\end{array}$ & Substances & $\begin{array}{l}\text { Exposure } \\
\text { time }\end{array}$ & Measurement & Findings \\
\hline 2017 [45] & $\begin{array}{l}\text { and } \\
\text { endocannabinoids }\end{array}$ & & & & $\begin{array}{l}\text { exposure, } \\
\text { after and } 24 \\
\mathrm{~h} \\
\text { postexposure }\end{array}$ & \\
\hline $\begin{array}{l}\text { Dantoft et al. } \\
2015 \text { [46] }\end{array}$ & $\begin{array}{l}\text { Cytokine and } \\
\text { chemokine in } \\
\text { epithelial lining } \\
\text { fluid }\end{array}$ & $18 / 18$ & $\begin{array}{l}\text { n-Butanol (below irritation } \\
\text { threshold) }\end{array}$ & $42 \mathrm{~min}$ & $\begin{array}{l}\text { After } 15 \text { min } \\
\text { of exposure }\end{array}$ & $\begin{array}{l}\text { No abnormal upper airway } \\
\text { inflammatory mediator levels }\end{array}$ \\
\hline $\begin{array}{l}\text { Dantoft et al. } \\
2017 \text { [47] }\end{array}$ & $\begin{array}{l}\text { Gene expression } \\
\text { for inflammatory } \\
\text { markers }\end{array}$ & $18 / 18$ & $\begin{array}{l}\text { n-Butanol (below irritation } \\
\text { threshold) }\end{array}$ & $42 \mathrm{~min}$ & $\begin{array}{l}\text { After } 15 \text { min } \\
\text { of exposure }\end{array}$ & $\begin{array}{l}\text { No differences in gene expression } \\
\text { levels before/after exposure }\end{array}$ \\
\hline $\begin{array}{l}\text { Georgellis et al. } \\
2003 \text { [48] }\end{array}$ & $\begin{array}{l}\text { Serum prolactin } \\
\text { and cortisol }\end{array}$ & $14 / 15$ & $\begin{array}{l}\text { Furfuryl mercaptan, } \\
\text { acetone, VOC mixture }\end{array}$ & $20 \mathrm{~min}$ & $\begin{array}{l}\text { Before and } \\
\text { after } \\
\text { exposure }\end{array}$ & No differences \\
\hline $\begin{array}{l}\text { Haumann et al. } \\
2003 \text { [49] }\end{array}$ & $\mathrm{RR}, \mathrm{HR}$ & $12 / 12$ & $\begin{array}{l}\text { Ethyl benzene, 2- } \\
\text { butanone, 2-propanol, 1- } \\
\text { octanol (above odor } \\
\text { threshold) }\end{array}$ & $4 \mathrm{~h}$ & $\begin{array}{l}\text { During } \\
\text { exposure }\end{array}$ & No differences \\
\hline $\begin{array}{l}\text { Hillert et al. } \\
2007 \text { [50] }\end{array}$ & PET & $12 / 12$ & $\begin{array}{l}\text { Vanillin, odorant acetone, } \\
\text { cedar oil, lavender oil, } \\
\text { eugenol, butanol, human } \\
\text { pheromones (above odor } \\
\text { threshold) }\end{array}$ & $15 s$ & During task & $\begin{array}{l}\text { Activated odor-processing brain re- } \\
\text { gions with odorant-related increase } \\
\text { in activation of the anterior cingu- } \\
\text { late cortex and cuneus-precuneus }\end{array}$ \\
\hline $\begin{array}{l}\text { Joffres et al. } \\
2005[51]\end{array}$ & $\begin{array}{l}\mathrm{SCA}, \mathrm{HR}, \mathrm{EMG}, \mathrm{RR}, \\
\text { cognitive test }\end{array}$ & $10 / 7$ & $\begin{array}{l}\text { Glue, body wash solution, } \\
\text { dryer sheet, unscented } \\
\text { shampoo }\end{array}$ & $5 \mathrm{~min}$ & During task & $\begin{array}{l}\text { Increased skin conductance, } \\
\text { suggesting involvement of the } \\
\text { premotor cortex, hypothalamus, } \\
\text { and limbic systems }\end{array}$ \\
\hline Kimata 2004 [52] & $\begin{array}{l}\text { Plasma SP, VIP, } \\
\text { NGF, and } \\
\text { histamine, and } \\
\text { skin prick tests }\end{array}$ & $25 / 25$ & $\begin{array}{l}\text { Plastic-based paint with } \\
\text { unpleasant odor } \\
\text { containing organic } \\
\text { solvents }\end{array}$ & $15 \mathrm{~min}$ & $\begin{array}{l}\text { Before and } \\
\text { after } \\
\text { exposure }\end{array}$ & $\begin{array}{l}\text { Increased plasma levels of all } \\
\text { parameters, suggesting enhanced } \\
\text { neurogenic inflammation }\end{array}$ \\
\hline $\begin{array}{l}\text { Millqvist et al. } \\
2005 \text { [53] }\end{array}$ & $\begin{array}{l}\text { NGF, nasal lavage } \\
\text { fluid }\end{array}$ & $\begin{array}{l}13 \text { sensory } \\
\text { hyperreactivity } \\
/ 14\end{array}$ & Capsaicin & $\begin{array}{l}\text { Over } 6 \text { min } \\
\text { (until } \\
\text { inducing } \\
\text { coughing) }\end{array}$ & $\begin{array}{l}\text { Before and } \\
\text { after } \\
\text { exposure }\end{array}$ & Increased NGF \\
\hline $\begin{array}{l}\text { Orriols et al. } \\
2009[54]\end{array}$ & SPECT & $8 / 8$ & $\begin{array}{l}\text { Plastic-based paint, } \\
\text { perfume, petrol, } \\
\text { glutaraldehyde (above } \\
\text { odor threshold) }\end{array}$ & $\begin{array}{l}3-35 \text { min } \\
\text { (until } \\
\text { inducing } \\
\text { symptoms) }\end{array}$ & $\begin{array}{l}\text { After } 15-30 \\
\text { min of } \\
\text { exposure }\end{array}$ & $\begin{array}{l}\text { Neurocognitive impairment and } \\
\text { dysfunction particularly in odor- } \\
\text { processing areas, suggesting a } \\
\text { neurogenic origin }\end{array}$ \\
\hline $\begin{array}{l}\text { Osterberg et al. } \\
2003 \text { [55] }\end{array}$ & $\begin{array}{l}\text { Neurobehavioral } \\
\text { test }\end{array}$ & $10 / 20$ & $\begin{array}{l}\text { n-Butyl acetate, toluene } \\
\text { (above odor threshold) }\end{array}$ & $70 \mathrm{~min}$ & $\begin{array}{l}\text { During } \\
\text { exposure }\end{array}$ & $\begin{array}{l}\text { Lower psychological test } \\
\text { performance during exposure }\end{array}$ \\
\hline $\begin{array}{l}\text { Papo et al. } \\
2006[56]\end{array}$ & EEG & $23 / 23$ & $\begin{array}{l}\text { Phenyl ethyl alcohol, } \\
\text { hydrogen sulfide (above } \\
\text { odor threshold) }\end{array}$ & $\begin{array}{l}200 \mathrm{~ms} \\
\text { repetition }\end{array}$ & During task & No differences \\
\hline
\end{tabular}

Abbreviations: $\mathrm{Cl}$ chemical intolerance, $\mathrm{CO}_{2}$ carbon dioxide, EEG electroencephalograph, EMG surface electromyogram, EOG electrooculogram, FDG F-2-fluoro-2deoxy-D-glucose, $f M R I$ functional magnetic resonance imaging, $f N I R S$ functional near-infrared spectroscopy, HR heart rate, $M C S$ multiple chemical sensitivity, NGF nerve growth factor, $P E T$ positron emission tomography, RR respiratory rate, SCA skin conductance activity, SP substance $P, S P E C T$ single photon-emission computed tomography, VIP vasoactive intestinal peptide, VOC volatile organic compound

repeated exposure to solvents emitted from a neighboring industrial plant or paint store, or exposure to fragrances, pesticides, or tobacco smoke emitted in their neighborhood. Patients with MCS subsequently reported a chemical sensitivity condition [32-34]. Other studies also reported initial episodes such as moving into a newly built home, exposure to chemicals at the workplace, use of solvents or pesticides, new carpet, building materials in remodeling, or medications
[2, 57-60]. However, there are some cases in which onset was reported as gradual and no specific event or exposure could be recalled by patients $[2,57]$.

Qualitative or quantitative data on past chemical exposure, and initiating events in particular, are often limited. In particular, quantitative data are almost never reported, and exposure concentrations from transient past events cannot be measured. In one patient, we 
measured average outdoor air concentrations over $24 \mathrm{~h}$ in the house of an MCS patient exposed to solvents emitted from a neighboring industrial plant. Although the patient sometimes suffered due to odor from the plants, we could not detect the solvents at concentrations that exceeded air quality standards or odor thresholds. The results might be affected by diurnal variations or shifting winds. However, the most important feature is that nearly instantaneous elevations (e.g., on the timescale of seconds) of air concentrations, which may exceed odor thresholds, cannot be measured as quantitative air concentrations using existing techniques, even though an individual may respond to the instantaneous exposure to odor and suffer as a result. This leads to the assumption that $\mathrm{CI}$ occurs when individuals are sensitized via repeated exposure to small amounts of chemicals, but these phenomena cannot be explained by existing toxicological knowledge. This also calls into question the definition of $\mathrm{CI}$, and evidence does not seem to support the requirement of a specific precipitating exposure event. Thus, specific exposure episodes in individuals with $\mathrm{CI}$ and specific modes of action at the onset of $\mathrm{CI}$ cannot be adequately examined using existing techniques or risk assessments.

\section{Human response to external environmental factors}

Humans respond to changes in their external environment in order to maintain homeostasis of their internal environment. Modern human diseases, including obesity, type-2 diabetes, atherosclerosis, autoimmunity, allergy, and certain psychiatric disorders, have two features in common: they involve disruption of homeostasis and are associated with chronic inflammation [61]. The nervous, endocrine, and immune systems play important roles in maintaining homeostasis. Changes in the external environment that affect an organism include exposure to physical, biological, and chemical stresses. The nervous system enacts the initial response against these changes, and the perceived signals are transmitted to the CNS by sensory nerves and are then quickly regulated by autonomic nerves [62].

The interrelationship between external stress and CNS responses is often described using a mechanistic model, shown in Fig. 1, of the exposure-outcome relationship of the human stress response [63]. In this model, it is necessary to focus on identifying important susceptibility factors and modifying factors, as well as ultimate changes in behavior, structure, and function in humans. Identifications of these factors, and appropriately and effectively controlling these factors, can result in the prevention of diseases caused by external environmental factors. When investigating the mechanism of action, exposure to external factors and outcomes should be elucidated, thereby defining condition-specific outcomes and triggers. It is also necessary to (i) investigate the loci of the brain involved in processing peripheral nervous system signals from the external environment into the CNS and to (ii) probe the relationship between this processing and modifying factors [63].

MCS appears to involve the sensation of extrinsic substances perceived as hazardous, particularly through olfaction, and involves high sensitivity to various odorous substances [32, 64]. Odor is composed of a single

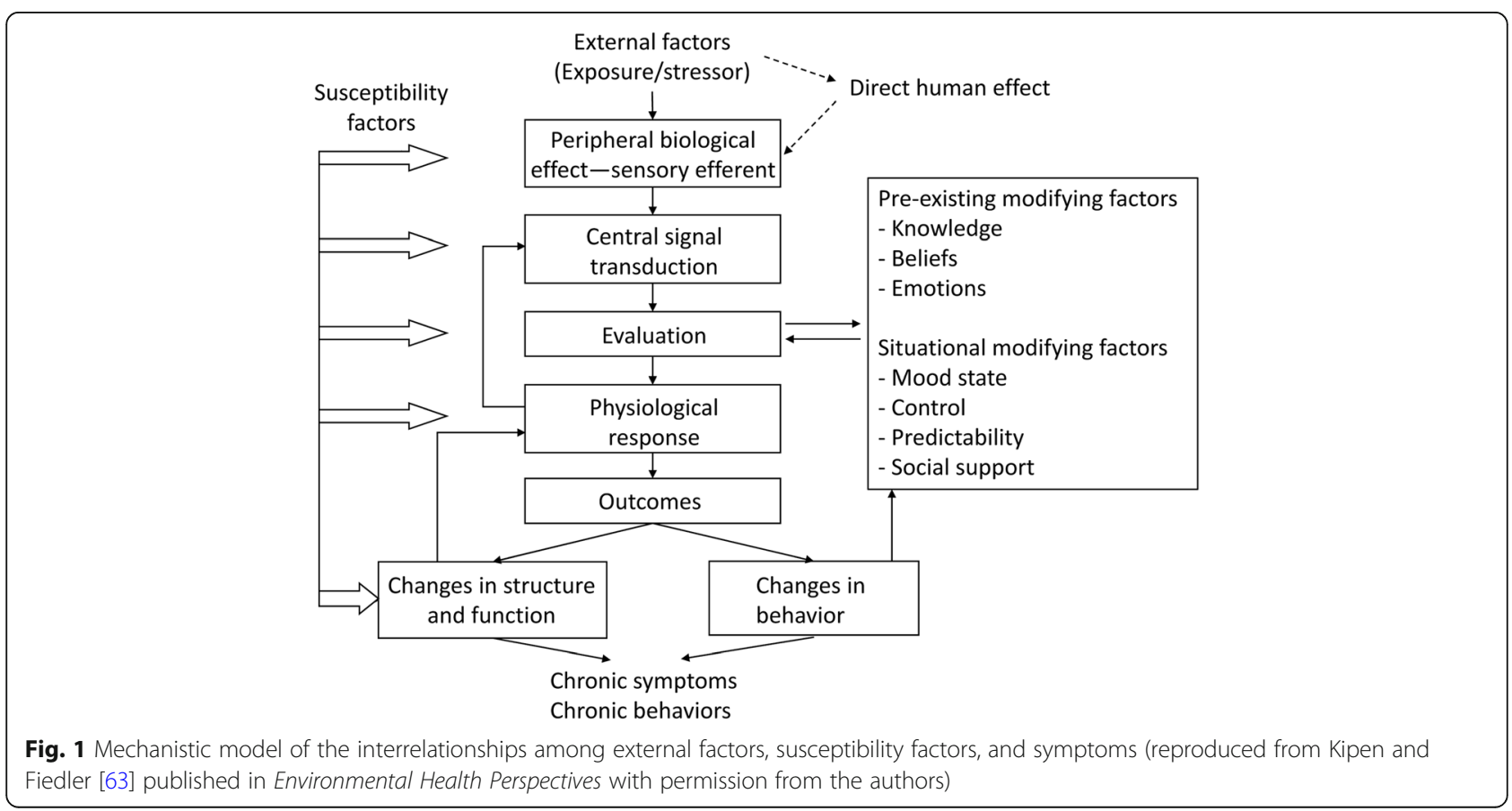


substance, or mixtures of multiple substances, and is cognized through multiple olfactory receptors. Thus, it is important to investigate the processing of these sensations through olfactory perception in the brain. Numerous modes of action have been suggested to explain CI, with the most commonly discussed theories involving the immune, central nervous, olfactory, and respiratory systems, as well as altered metabolic capacity, behavioral conditioning, and emotional regulation $[1,65]$.

\section{Neurological responses to chemical exposure}

Table 1 summarizes the experimental human studies directly associated with CI or MCS, including IEI due to chemical exposure and related neurological responses or brain imaging studies after exposure to odorous or pungent substances.

Olfactory input directly connects from the olfactory bulb and primary olfactory (piriform) cortex to the amygdala and hippocampus. From these areas, sensory information is conveyed to the secondary olfactory cortices, composed of the orbitofrontal cortex and insular cortex [66]. The olfactory and trigeminal systems are intimately connected and work closely together in the perception of an odorant as most odorants stimulate both sensory systems and despite the fact that trigeminal perception is independent from olfactory processing [67, 68]. A stimulus that activates the trigeminal system evokes cerebral activation of somatosensory regions as well as primary olfactory areas, such as the piriform cortex and orbitofrontal cortex [69].

On the basis of these insights, several studies have used brain imaging to compare metabolic patterns of different brain areas in individuals with CI or MCS versus healthy controls when exposed to odorous or pungent substances. Among the studies shown in Table 1, those assessing cerebral activity in response to several different odorous or pungent stimuli using positron emission tomography (PET), functional magnetic resonance imaging (fMRI), functional near-infrared spectroscopy (fNIRS), and single photon-emission computed tomography (SPECT) found that patients with MCS or CI processed odors differently from controls [32-34, 38, 40, 41, 43, 50, 54].

Hillert et al. reported that regions of the brain engaged in odor processing (the amygdala, piriform cortex, and insular cortex) were less active in MCS patients than in controls in PET imaging when exposed to odorant above the odor threshold. Furthermore, an odorant-related increase in activation of the anterior cingulate cortex (ACC) and cuneus/precuneus was observed [50]. Using fNIRS, Azuma et al. reported increased activation in the prefrontal cortex (PFC) during olfactory stimulation and in the orbitofrontal cortex after olfactory stimulation above the odor threshold in patients with MCS [32-34]. In these studies, subjects were exposed to an odorant for a short period of time (10 or $15 \mathrm{~s}$ ), and imaging data were collected during and immediately after exposure. Thus, the results reflect instantaneous responses of odor-processing neuronal circuits. Andersson et al. also reported greater reactions in the olfactory region of the orbitofrontal cortex during a 30-s exposure using fMRI, especially in the first $15 \mathrm{~s}$ of exposure [40].

Chiaravalloti et al. used brain glucose consumption in PET imaging to show that cortical odor processing in subjects with MCS was characterized by a decrease in activity of the frontal cortex and by activation of the left inferior temporal gyrus [43]. The same group reported a peculiar subcortical activation pattern in subjects with MCS, with enhanced glucose consumption in the bilateral olfactory region, suggesting a potentially useful metabolic index correlated with MCS complaints [38]. These results suggest hyperreactivity and limbic sensitization with neurogenic inflammation. Orriols et al. reported neurocognitive impairment based on SPECT imaging in subjects with MCS and identified brain dysfunction, particularly in odor-processing areas such as the hippocampus, amygdala, and thalamus, when subjects were exposed to odorants above the odor threshold, thereby suggesting a neurogenic origin of MCS [54]. In these studies, subjects were exposed to an odorant for longer durations (9 $\mathrm{min}$ and $3-35 \mathrm{~min}$ ), and imaging data were collected at $24 \mathrm{~min}$ or $15-30 \mathrm{~min}$ after exposure (compared with previously mentioned studies on the timescale of seconds). Thus, these longer timescale results might reflect affective stress responses after chemical exposure.

Odor processing is instantaneous. An odor can almost instantly key our memory to recall personal events and situations $[70,71]$. The function of odor perception is to continually monitor the environment and categorize odors into one of two large categories: those to approach or those to avoid [72]. As shown in Table 1, after the beginning of exposure to odorous or pungent substances, studies reported altered autonomic responses [23, 51], attention bias [39], neurocognitive worsening [54], lower psychological test performance [55], and enhanced neurogenic inflammation $[52,53]$ in subjects with $\mathrm{MCI}$ or CI. However, levels of serum prolactin and cortisol involved in psychological stress $[42,48]$, oxylipins and endocannabinoids involved in signaling during inflammation [45], cytokines and chemokines in epithelial lining fluid [46], gene expression of inflammatory markers [47], respiratory rate [49], and static electrical parameter $[44,56]$ were not different compared with healthy controls after exposure to odorous or pungent substances.

\section{Discussion and outlook}

The dorsal portion of the ACC is connected to the PFC and plays an important role in processing top-down and 
bottom-up stimuli and assigning appropriate control to other areas of the brain [73]. Both the ACC and orbitofrontal cortex are implicated in decision-making, emotion, and social behavior. The orbitofrontal cortex is involved in cognitive processing of stimuli and representation of preferences [74]. CI occurs when individuals are first sensitized via an initial exposure to a certain amount of chemical or repeated exposure to small amounts of chemical. On re-exposure, individuals become increasingly sensitized; often, the effects spread, and individuals become sensitized to several additional chemicals [4]. Numerous studies have reported that odor detection thresholds [34, 50, 64, 75-77] and odor identification $[75,78,79]$ occurred at similar levels between subjects with MCS or CI and controls. Although significant differences in odor detection and recognition thresholds were not observed, brain responses at the recognition threshold level were stronger in subjects with MCS [34, 50], and perceived intensity and unpleasantness of odors were significantly higher for subjects with MCS [80].

Human episodic memory involves the long-term memory process that enables one to mentally and consciously relive specific personal events from the past [81, 82]. In particular, episodic odor memory undergoes extremely little longterm loss compared with memories of pictures or odor presented in a laboratory environment [83], and odors appear to trigger the most vivid and emotional memories [84]. Emotional processing related to stimulation with or discomfort to odor prevails, and the consequences of the processing appear rapidly $[66,83]$. The PFC regulates the formation and control of memory $[85,86]$ and plays an important role in long-term odor memory [71, 87].

Individuals with CI exhibit stronger physical and psychological reactions to odorous or pungent substances at normally perceived levels in daily life than healthy people. This status persists due to repeated daily exposure to these substances, and they exhibit physical and psychological intolerance to the substances at levels less than those established to have harmful effects in the general population [32]. Thus, in the mechanism of CI, past exposure is stored as memory in the PFC connected from the ACC through olfactory nerve circuits. The processing of top-down stimuli from these cortices involves the central system related to emotional and the autonomic nervous system, and various physical or psychological symptoms may be induced in subjects with $\mathrm{CI}$ in later life when individuals with $\mathrm{CI}$ are exposed to odorous or pungent substances. Such responses in odor processing are associated with cognition and memory processes in the brain and occur when an individual distinguishes between a nonagent substance and an agent substance (i.e., approach or avoid). This means that the mode of action in this response is not specific to individual substances, but is associated with a past event such as exposure to odorous or pungent substances, and this mode of action involves responses to multiple chemicals in CI. Interestingly, it has been reported that symptoms can occur with odors associated with negative events [88] and generalization of acquired somatic symptoms in response to odorous substances [89].

Although some studies reported neurogenic inflammation after exposure to odorous or pungent substances, including hypoactivation of frontal and prefrontal areas $[38,43]$, these results might reflect affective stress responses after chemical exposure. Dantoft et al. reported increased levels of proinflammatory cytokines, including interleukin-1 $\beta$ (IL-1 $\beta$ ), interleukin-6 (IL-6), and tumor necrosis factor- $\alpha$ (TNF- $\alpha)$, and inverse regulation of Th2-associated cytokines interleukin-4 and interleukin13 , in unexposed subjects with MCS, suggesting a deviating Th2-associated cytokine response not involving IgE-mediated mechanisms [90]. A similar profile of proinflammatory mediators, including increased levels of IL$1 \beta$, IL- 6 , and TNF- $\alpha$, has been reported in depression and stress, which are thought to be inflammatory responses of microglial activation after stress or environmental cues such as stranger and danger signals [91-94]. Studies on the involvement of brain microglia in stress have been reported since 2005 [95], and the association with acute stress was first reported in 2007 [96]. Exploring the involvement of microglia in $\mathrm{CI}$ may provide new insight into the mechanisms of CI. In addition, studies have shown an association of increased severity of post-traumatic stress disorder (PTSD) and neuropsychological performance with decreased medial PFC and rostral ACC activity [97], as well as an association of greater severity of depression and somatic symptoms with less synaptic density in the dorsolateral PFC, ACC, and hippocampus [98]. Thus, neurogenic inflammation in CI or MCS is considered to be the brain's response to stress or negative psychosomatic status after exposure to unpleasant substances rather than a result of toxicological effects.

On the basis of these studies, we suggest a sensory and cognition model of the interrelationships between extrinsic stimuli, the limbic system, cortices, symptoms, and responses (Fig. 2). Nordin proposed central sensitization as a possible mechanism of $\mathrm{CI}$ and called this a chemosensory model [99]. The results of our review and this model led to a great outlook for derivation of our model. We proposed a sensory and cognition model (Fig. 2) based on the mechanistic model shown in Fig. 1 and also considered the importance of processing extrinsic stimuli and cognition of sensation involving the limbic system and PFC. When individuals first receive strong stimulation or stress via an initial exposure to a certain amount of chemical or repeated exposure to small amounts of chemical, the stimulation or stress is strongly cognized by an odorprocessing neuronal circuit and stored as memory in the 


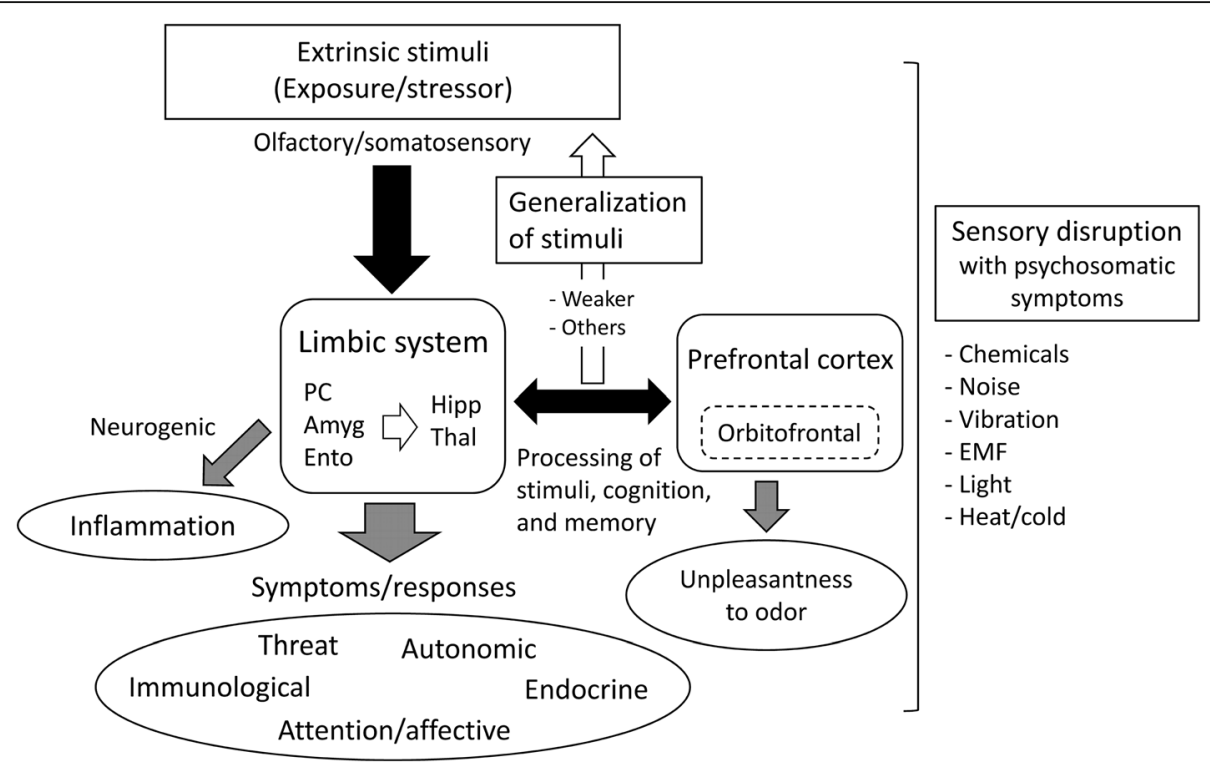

Fig. 2 Sensory and cognition model of the interrelationships among stimulus factors, limbic system, cortices, symptoms, and responses. Abbreviations: Amyg, amygdala; EMF, electromagnetic field; Ento, entorhinal cortex; Hipp, hippocampus; PC, piriform cortex; Thal, thalamus

PFC area through the limbic system; the stimulus is subsequently generalized. Once generalized, even if individuals are later exposed to weaker stimuli, they recognize it as strong stimulation or stress, which induces various symptoms through the limbic system and PFC. In light of this model, distracting attention from odorous or pungent substances may be effective for the recovery from CI status, resulting in the treatment of $\mathrm{CI}$. In the clinical practice, adequate assessment of exposure history for identifying the agent substance which should be avoided would have an important role for the recovery of a patient with CI [100]. Interestingly, a 5-year follow-up study reported that appropriate physical activity and maintaining a regular lifestyle, including diet or sleep, were significant factors for the improvement of CI [101]. However, the detailed neurological and pathological mechanism through the limbic system and the role of PFC or orbitofrontal cortex in the onset of $\mathrm{CI}$ and appearance of symptoms in individuals with CI remain unclear. Similarly increased PFC activity is suggested in incidences of experimental pain under chronic clinical pain conditions [102]. Further research into these mechanisms is required.

Three 5-year follow-up studies reported that participants who developed CI between baseline and follow-up reported more health complaints or negative psychosomatic states at baseline compared to participants who did not develop CI [101, 103, 104]. An association of risk of acquiring $\mathrm{CI}$ with measures of inherent physical constitution, such as cold sensitivity or the presence of an indoor cat during childhood, has also been reported [105]. In this study, the prevalence of current $\mathrm{CI}$ in mothers was $4.5 \%$ and in their 3-year-old children was $0.25 \%$, or approximately one eighteenth of that reported by their mothers [105]. Devriese et al. reported that generalization of acquired somatic symptoms in response to odorous substances especially occurred in individuals with high negative affectivity [89]. Thus, negative status or inherent constitution may cause greater susceptibility to CI. In addition, one's housing environment in childhood is an important risk factor for CI. Finally, such a generalized pathological condition due to disturbance of sensation may lead to the symptoms induced by other stressors such as noise, vibration, electromagnetic field, light, or excess heat or cold. Such conditions can be regarded as a sensory disruption with psychosomatic symptoms (Fig. 2).

\section{Conclusions}

This review highlights evidence from studies conducted during the past two decades on our understanding of brain function and networks after exposure to extrinsic stimuli and how these relate to CI status. As the review indicates, our understanding of the mechanisms of $\mathrm{CI}$ has gradually increased by using chemical provocation tests along with brain imaging techniques, and these studies have made multiple contributions to elucidate the mode of CI. There is consistent evidence that altered neurological processing of sensory information contributes to CI status. However, neurophysiological research exploring the processing of extrinsic stimuli and cognition of sensation through the limbic system and related cortices in the onset of $\mathrm{CI}$ is required. Future research elucidating the mechanisms of CI will impact clinical practice and thus contribute to a decreased prevalence of $\mathrm{CI}$ in society. 


\section{Abbreviations}

ACC: Anterior cingulate cortex; Amyg: Amygdala; Cl: Chemical intolerance; CNS: Central nervous system; $\mathrm{CO}_{2}$ : Carbon dioxide;

EEG: Electroencephalograph; EMF: Electromagnetic field; EMG: Surface electromyogram; Ento: Entorhinal cortex; EOG: Electrooculogram; FDG: F-2fluoro-2-deoxy-D-glucose; fMRI: Functional magnetic resonance imaging; fNIRS: Functional near-infrared spectroscopy; Hipp: Hippocampus; HR: Heart rate; IEl: Idiopathic environmental intolerance; IL-1 $\beta$ : Interleukin-1 $\beta$; IL6: Interleukin-6; MCS: Multiple chemical sensitivity; NGF: Nerve growth factor; PC: Piriform cortex; PET: Positron emission tomography; PFC: Prefrontal cortex; PTSD: Post-traumatic stress disorder; RR: Respiratory rate; SCA: Skin conductance activity; SP: Substance P; SPECT: Single photon-emission computed tomography; Thal: Thalamus; TNF-a: Tumor necrosis factor-a; VIP: Vasoactive intestinal peptide; VOC: Volatile organic compound

\section{Acknowledgments}

Not applicable.

\section{Authors' contributions}

The eight authors are justifiably credited with authorship, according to the authorship criteria. In detail, KA contributed to the conception, design, acquisition and interpretation of data, drafting of the manuscript, and final approval given; IU to the conception, design, interpretation of data, critical revision of manuscript, and final approval given; MT, IB, and MA to the interpretation of data and critical revision of manuscript from each expertise and final approval given; HT to the conception, interpretation of data, and critical revision of manuscript, final approval given; and TY and KS to the conception, critical revision of manuscript, and final approval given.

\section{Funding}

This study was financially supported by a Grant-in-Aid for Scientific Research (16K09116, 17K09179) provided by the Japan Ministry of Education, Culture, Sports, Science and Technology. The funders had no role in study design, data collection and analysis, decision to publish, or preparation of the manuscript. http://www.jsps.go.jp/english/e-grants/index.html

\section{Availability of data and materials}

Not applicable.

\section{Ethics approval}

Not applicable.

\section{Consent for publication}

Not applicable.

\section{Competing interests}

The authors declare that they have no competing interests.

\section{Author details}

'Department of Environmental Medicine and Behavioral Science, Kindai University Faculty of Medicine, 377-2 Ohnohigashi, Osakasayama, Osaka 589-8511, Japan. ${ }^{2}$ Sick-house Medical Science Laboratory, Division of Basic Research, Louis Pasteur Center for Medical Research, Kyoto 606-8225, Japan. ${ }^{3}$ Outpatient Department of Sick-house Syndrome, Hyakumanben Clinic, Kyoto 606-8225, Japan. ${ }^{4}$ Clinical Immune Function Laboratory, Division of Basic Research, Louis Pasteur Center for Medical Research, Kyoto 606-8225, Japan. ${ }^{5}$ Faculty of Education, Home Economics, Tokyo Gakugei University, Koganei 184-8501, Japan. ${ }^{6}$ Department of Human Environmental Design, Faculty of Health Science, Kio University, Kitakatsuragi-gun 635-0832, Japan. ${ }^{7}$ Department of Environmental Engineering, Graduate School of Engineering, Kyoto University, Kyoto, Japan. ${ }^{8}$ Department of Anatomy and Cellular Biology, Tokai University School of Medicine, Isehara 259-1193, Japan.

\section{Received: 20 August 2019 Accepted: 23 September 2019}

Published online: 22 October 2019

\section{References}

1. Dantoft T, Andersson L, Nordin S, Skovbjerg S. Chemical intolerance. Curr Rheumatol Rev. 2015;11:167-84.

2. Graveling RA, Pilkington A, George JP, Butler MP, Tannahill SN. A review of multiple chemical sensitivity. Occup Environ Med. 1999;56:73-85.
3. Karvala K, Sainio M, Palmquist E, Nyback MH, Nordin S. Prevalence of various environmental intolerances in a Swedish and Finnish general population. Environ Res. 2018;161:220-8.

4. Cullen MR. The worker with multiple chemical sensitivities: an overview. Occup Med. 1987;2:655-61.

5. Sakabe K, Kimura M, Terayama H, Tsunoda M, Miyajima E, Takano H, Azuma K, Mizukoshi A, Matsuda T, Mori C, Kawakami S, Miyata M, Ishikawa S, Aizawa Y. Chemical sensitivity - the frontier of diagnosis and treatment. Jpn J Clin Ecol. 2016;25:49-54.

6. Winder C. Mechanisms of multiple chemical sensitivity. Toxicol Lett. 2002;128:85-97.

7. Berg ND, Linneberg A, Dirksen A, Elberling J. Phenotypes of individuals affected by airborne chemicals in the general population. Int Arch Occup Environ Health. 2009:82:509-17.

8. Hausteiner C, Bornschein S, Hansen J, Zilker T, Förstl H. Self-reported chemical sensitivity in Germany: a population-based survey. Int J Hyg Environ Health. 2005;208:271-8.

9. Lacour M, Zunder T, Schmidtke K, Vaith P, Scheidt C. Multiple chemical sensitivity syndrome (MCS) — suggestions for an extension of the U.S. MCScase definition. Int J Hyg Environ Health. 2005;208:141-51.

10. Sorg BA. Multiple chemical sensitivity: potential role for neural sensitization. Crit Rev Neurobiol. 1999:13:283-316.

11. Andersson L, Johansson Å, Millqvist E, Nordin S, Bende M. Prevalence and risk factors for chemical sensitivity and sensory hyperreactivity in teenagers. Int J Hyg Environ Health. 2008;211:690-7.

12. Azuma K, Uchiyama I, Katoh T, Ogata H, Arashidani K, Kunugita N. Prevalence and characteristics of chemical intolerance: a Japanese population-based study. Arch Environ Occup Health. 2015;70:341-53.

13. Berg ND, Linneberg A, Dirksen A, Elberling J. Prevalence of self-reported symptoms and consequences related to inhalation of airborne chemicals in a Danish general population. Int Arch Occup Environ Health. 2008:81:881-7.

14. Caress SM, Steinemann AC. A review of a two-phase population study of multiple chemical sensitivities. Environ Health Perspect. 2003;111:1490-7.

15. Caress SM, Steinemann AC. Prevalence of multiple chemical sensitivities: a population-based study in the southeastern United States. Am J Public Health. 2004;94:746-7

16. Carlsson F, Karlson B, Ørbaek P, Osterberg K, Ostergren PO. Prevalence of annoyance attributed to electrical equipment and smells in a Swedish population, and relationship with subjective health and daily functioning. Public Health. 2005;119:568-77.

17. Johansson A, Brämerson A, Millqvist E, Nordin S, Bende M. Prevalence and risk factors for self-reported odour intolerance: the Skövde population-based study. Int Arch Occup Environ Health. 2005;78:559-64.

18. Kreutzer R, Neutra RR, Lashuay N. Prevalence of people reporting sensitivities to chemicals in a population-based survey. Am J Epidemiol. 1999;150:1-12.

19. Meggs WJ, Dunn KA, Bloch RM, Goodman PE, DavidoV AL. Prevalence and nature of allergy and chemical sensitivity in a general population. Arch Environ Health. 1996;53:275-82.

20. Skovbjerg S, Berg ND, Elberling J, Christensen KB. Evaluation of the quick environmental exposure and sensitivity inventory in a Danish population. J Environ Public Health. 2012:304314. https://doi.org/10.1155/2012/304314.

21. Steinemann A. National prevalence and effects of multiple chemical sensitivities. J Occup Environ Med. 2018:60:e152-6.

22. Steinemann A. Prevalence and effects of multiple chemical sensitivities in Australia. Prev Med Rep. 2018:10:191-4.

23. Andersson L, Claeson AS, Dantoft TM, Skovbjerg S, Lind N, Nordin S. Chemosensory perception, symptoms and autonomic responses during chemical exposure in multiple chemical sensitivity. Int Arch Occup Environ Health. 2016;89:79-88.

24. American Academy of Allergy Asthma and immunology (AAAAI) Board of Directors. Idiopathic environmental intolerances. J Allergy Clin Immunol. 1999:103:36-40.

25. American College of Occupational and Environmental Medicine (ACOEM). ACOEM position statement. Multiple chemical sensitivities: idiopathic environmental intolerance. College of Occupational and Environmental Medicine. J Occup Environ Med. 1999;41:940-2.

26. Bornschein S, Förstl H, Zilker T. Idiopathic environmental intolerances (formerly multiple chemical sensitivity) psychiatric perspectives. J Intern Med. 2001;250:309-21.

27. Bornschein S, Hausteiner C, Zilker T, Förstl H. Psychiatric and somatic disorders and multiple chemical sensitivity (MCS) in 264 'environmental patients'. Psychol Med. 2002;32:1387-94. 
28. Hausteiner C, Bornschein S, Zilker T, Henningsen P, Förstl H. Dysfunctional cognitions in idiopathic environmental intolerances (IEI) —an integrative psychiatric perspective. Toxicol Lett. 2007;171:1-9.

29. International Programme on Chemical Safety (IPCS). Report of the workshop on multiple chemical sensitivities (MCS), Berlin, Germany, 21-23 February 1996. World Health Organization, Programme for the Promotion of Chemical Safety \& International Programme for Chemical Safety, Geneva, 1996. https://apps.who.int/iris/handle/10665/63109 (Accessed 12 July 2019).

30. Anonymous. Multiple chemical sensitivity: a 1999 Consensus. Arch Environ Health. 1999:54:147-9.

31. Rossi S, Pitidis A. Multiple chemical sensitivity: review of the state of the art in epidemiology, diagnosis, and future perspectives. J Occup Environ Med. 2018;60:138-46.

32. Azuma K, Uchiyama I, Takano H, Tanigawa M, Azuma M, Bamba I, Yoshikawa T. Changes in cerebral blood flow during olfactory stimulation in patients with multiple chemical sensitivity: a multi-channel near-infrared spectroscopic study. PLoS One. 2013;8(11):e80567. https:/doi.org/10.1371/journal.pone.0080567.

33. Azuma K, Uchiyama I, Tanigawa M, Bamba I, Azuma M, Takano H, Yoshikawa T, Sakabe K. Assessment of cerebral blood flow in patients with multiple chemical sensitivity using near-infrared spectroscopy--recovery after olfactory stimulation: a case-control study. Environ Health Prev Med. 2015;20:185-94.

34. Azuma K, Uchiyama I, Tanigawa M, Bamba I, Azuma M, Takano H, Yoshikawa T, Sakabe K. Association of odor thresholds and responses in cerebral blood flow of the prefrontal area during olfactory stimulation in patients with multiple chemical sensitivity. PLoS One. 2016;11(12):e0168006. https://doi. org/10.1371/journal.pone.0168006.

35. Das-Munshi J, Rubin GJ, Wessely S. Multiple chemical sensitivities: a systematic review of provocation studies. J Allergy Clin Immunol. 2006;118:1257-64.

36. Tran MT, Arendt-Nielsen L, Kupers R, Elberling J. Multiple chemical sensitivity: on the scent of central sensitization. Int J Hyg Environ Health. 2013;216:202-10.

37. Viziano A, Micarelli A, Pasquantonio G, Della-Morte D, Alessandrini M. Perspectives on multisensory perception disruption in idiopathic environmental intolerance: a systematic review. Int Arch Occup Environ Health. 2018;91:923-35.

38. Alessandrini M, Micarelli A, Chiaravalloti A, Bruno E, Danieli R, Pierantozzi M, Genovesi G, Öberg J, Pagani M, Schillaci O. Involvement of subcortical brain structures during olfactory stimulation in multiple chemical sensitivity. Brain Topogr. 2016;29:243-52.

39. Andersson L, Bende M, Millqvist E, Nordin S. Attention bias and sensitization in chemical sensitivity. J Psychosom Res. 2009;66:407-16.

40. Andersson L, Claeson AS, Nyberg L, Stenberg B, Nordin S. Brain responses to olfactory and trigeminal exposure in idiopathic environmental illness (IEI) attributed to smells_an fMRI study. J Psychosom Res. 2014;77:401-8.

41. Andersson L, Claeson AS, Nyberg L, Nordin S. Short-term olfactory sensitization involves brain networks relevant for pain, and indicates chemical intolerance. Int J Hyg Environ Health. 2017;220(2 Pt B):503-9.

42. Bornschein S, Hausteiner C, Römmelt H, Nowak D, Förstl H, Zilker T. Double -blind placebo-controlled provocation study in patients with subjective multiple chemical sensitivity and matched control subjects. Clin Toxicol. 2008;46:443-9.

43. Chiaravalloti A, Pagani M, Micarelli A, Di Pietro B, Genovesi G, Alessandrini M, Schillaci O. Cortical activity during olfactory stimulation in multiple chemical sensitivity: a (18)F-FDG PET/CT study. Eur J Nucl Med Mol Imaging. 2015;42:733-40.

44. Claeson AS, Andersson L. Symptoms from masked acrolein exposure suggest altered trigeminal reactivity in chemical intolerance. Neurotoxicology. 2017;60:92-8.

45. Claeson AS, Gouveia-Fiqueira S, Häggström J, Fowler CJ, Nording ML. Levels of oxylipins, endocannabinoids and related lipids in plasma before and after lowlevel exposure to acrolein in healthy individuals and individuals with chemical intolerance. Prostaglandins Leukot Essent Fatty Acids. 2017;121:60-7.

46. Dantoft TM, Skovbjerg S, Andersson L, Claeson AS, Lind N, Nordin S, Brix S. Inflammatory mediator profiling of $n$-butanol exposed upper airways in individuals with multiple chemical sensitivity. PLoS One. 2015;10(11): e0143534. https://doi.org/10.1371/journal.pone.0143534.

47. Dantoft TM, Skovbjerg S, Andersson L, Claeson AS, Engkilde K, Lind N, Nordin S, Hellgren LI. Gene expression profiling in persons with multiple chemical sensitivity before and after a controlled n-butanol exposure session. BMJ Open. 2017;7(2):e013879. https://doi.org/10.1136/bmjopen-2016-013879.

48. Georgellis A, Lindelof B, Lundin A, Arnetz B, Hillert L. Multiple chemical sensitivity in male painters; a controlled provocation study. Int J Hyg Environ Health. 2003;206:531-8.
49. Haumann K, Kiesswetter E, van Thriel C, Blaszkewicz M, Golka K, Seeber A. Breathing and heart rate during experimental solvent exposure of young adults with selfreported multiple chemical sensitivity (sMCS). Neurotoxicology. 2003;24:179-86.

50. Hillert L, Musabasic V, Berglund H, Ciumas C, Savic I. Odor processing in multiple chemical sensitivity. Hum Brain Mapp. 2007;28:172-82.

51. Joffres MR, Sampalli T, Fox RA. Physiologic and symptomatic responses to low-level substances in individuals with and without chemical sensitivities: a randomized controlled blinded pilot booth study. Environ Health Perspect. 2005;113:1178-83.

52. Kimata $\mathrm{H}$. Effect of exposure to volatile organic compounds on plasma levels of neuropeptides, nerve growth factor and histamine in patients with self-reported multiple chemical sensitivity. Int J Hyg Environ Health. 2004; 207:159-63.

53. Millqvist E, Ternesten-Hasséus E, Ståhl A, Bende M. Changes in levels of nerve growth factor in nasal secretions after capsaicin inhalation in patients with airway symptoms from scents and chemicals. Environ Health Perspect. 2005;113:849-52.

54. Orriols R, Costa R, Cuberas G, Jacas C, Castell J, Sunyer J. Brain dysfunction in multiple chemical sensitivity. J Neurol Sci. 2009;287:72-8.

55. Osterberg K, Orbaek P, Karlson B, Akesson B, Bergendorf U. Annoyance and performance during the experimental chemical challenge of subjects with multiple chemical sensitivity. Scand J Work Environ Health. 2003:29:40-50.

56. Papo D, Eberlein-König B, Berresheim HW, Huss-Marp J, Grimm V, Ring J, Behrendt $\mathrm{H}$, Winneke $\mathrm{G}$. Chemosensory function and psychological profile in patients with multiple chemical sensitivity: comparison with odorsensitive and asymptomatic controls. J Psychosom Res. 2006;60:199-209.

57. Fiedler N, Kipen H. Chemical sensitivity: the scientific literature. Environ Health Perspect. 1997;105(Suppl 2):409-15.

58. Ross GH. Clinical characteristics of chemical sensitivity: an illustrative case history of asthma and MCS. Environ Health Perspect. 1997;105(Suppl 2):437-41.

59. Saito M, Kumano H, Yoshiuchi K, Kokubo N, Ohashi K, Yamamoto Y, Shinohara N, Yanagisawa Y, Sakabe K, Miyata M, Ishikawa S, Kuboki T. Symptom profile of multiple chemical sensitivity in actual life. Psychosom Med. 2005;67:318-25.

60. Ziem G, McTamney J. Profile of patients with chemical injury and sensitivity. Environ Health Perspect. 1997;105(Suppl 2):417-36.

61. Kotas ME, Medzhitov R. Homeostasis, inflammation, and disease susceptibility. Cell. 2015;160:816-27.

62. Chapman CR, Tuckett RP, Song CW. Pain and stress in a systems perspective: reciprocal neural, endocrine and immune interactions. J Pain. 2008:9:122-45.

63. Kipen HM, Fiedler N. The role of environmental factors in medically unexplained symptoms and related syndromes: conference summary and recommendations. Environ Health Perspect. 2002;110(Suppl 4):591-5.

64. Doty RL, Deems DA, Frye RE, Pelberg R, Shapiro A. Olfactory sensitivity, nasal resistance, and autonomic function in patients with multiple chemical sensitivities. Arch Otolaryngol Head Neck Surg. 1988;144:1422-7.

65. Frías Á. Idiopathic environmental intolerance: a comprehensive and up-todate review of the literature. CNS. 2015;1:31-7.

66. Saive AL, Royet JP, Plailly J. A review on the neural bases of episodic odor memory: from laboratory-based to autobiographical approaches. Front Behav Neurosci. 2014;8:240. https://doi.org/10.3389/fnbeh.2014.00240.

67. Frasnelli J, Schuster B, Hummel T. Interactions between olfaction and the trigeminal system: what can be learned from olfactory loss. Cereb Cortex. 2007;17:2268-75.

68. Tremblay C, Frasnelli J. Olfactory and trigeminal systems interact in the periphery. Chem Senses. 2018;43:611-6.

69. Boyle JA, Heinke M, Gerber J, Frasnelli J, Hummel T. Cerebral activation to intranasal chemosensory trigeminal stimulation. Chem Senses. 2007;32:343-53.

70. Thomas-Danguin T, Sinding C, Romagny S, El Mountassir F, Atanasova B, Le Berre E, Le Bon AM, Coureaud G. The perception of odor objects in everyday life: a review on the processing of odor mixtures. Front Psychol. 2014;5:504. https://doi.org/10.3389/fpsyg.2014.00504 eCollection 2014.

71. Savic I, Gulyas B, Larsson M, Roland P. Olfactory functions are mediated by parallel and hierarchical processing. Neuron. 2000;26:735-45.

72. Stevenson RJ. An initial evaluation of the functions of human olfaction. An initial evaluation of the functions of human olfaction. Chem Senses. 2010;35:3-20.

73. Etkin $\mathrm{A}$, Egner $\mathrm{T}$, Kalisch R. Emotional processing in anterior cingulate and medial prefrontal cortex. Trends Cogn Sci. 2011;15:85-93.

74. Rushworth MF, Behrens TE, Rudebeck PH, Walton ME. Contrasting roles for cingulate and orbitofrontal cortex in decisions and social behaviour. Trends Cogn Sci. 2007;11:168-76. 
75. Caccappolo E, Kipen H, Kelly-McNeil K, Knasko S, Hamer RM, Natelson B, Fiedler N. Odor perception: multiple chemical sensitivities, chronic fatigue, and asthma. J Occup Environ Med. 2000;42:629-38.

76. Doty RL. Olfaction and multiple chemical sensitivity. Toxicol Ind Health. 1994;10:359-68.

77. Nordin S, Martinkauppi M, Olofsson J, Hummel T, Millqvist E, Bende M. Chemosensory perception and event-related potentials in selfreported chemical hypersensitivity. Int J Psychophysiol. 2005;55:243-55.

78. Fiedler N, Kipen HM, DeLuca J, Kelly-McNeil K, Natelson B. A controlled comparison of multiple chemical sensitivities and chronic fatigue syndrome. Psychosom Med. 1996:58:38-49.

79. Ojima M, Tonori H, Sato T, Sakabe K, Miyata M, Ishikawa S, Aizawa Y. Odor perception in patients with multiple chemical sensitivity. Tohoku J Exp Med. 2002;198:163-73.

80. Bamba I, Azuma K, Azuma M, Tanigawa M, Uchiyama I. Olfactory perception in multiple chemical sensitivity patients. J Japan Assoc on Odor Environ. 2019:50:27-39.

81. Tulving E. Episodic and semantic memory. In: Tulving E, Donaldson W, editors. Organization of Memory. New York: Academic Press; 1972. p. 381-403.

82. Tulving E. Précis of elements of episodic memory. Behav Brain Sci. 1984;7:223-68.

83. Engen T. Remembering odors and their names. Amer Scientist. 1987;75:497-503.

84. Hinton PB, Henley TB. Cognitive and affective components of stimuli presented in three modes. Bull Psychon Soc. 1993;31:595-8.

85. Simons JS, Spiers HJ. Prefrontal and medial temporal lobe interactions in long-term memory. Nat Rev Neurosci. 2003;4:637-48.

86. Tulving E. Episodic memory: from mind to brain. Annu Rev Psychol. 2002;53:1-25

87. Dade LA, Zatorre RJ, Jones-Gotman M. Olfactory learning: convergent findings from lesion and brain imaging studies in humans. Brain. 2002 125(Pt 1):86-101.

88. Devriese S, Winters W, Van Diest I, De Peuter S, Vos G, Van de Woestijne K, Van den Bergh O. Perceived relation between odors and a negative event determines learning of symptoms in response to chemicals. Int Arch Occup Environ Health. 2004;77:200-4.

89. Devriese S, Winters W, Stegen K, Van Diest I, Veulemans H, Nemery B, Eelen P, Van de Woestijne K, Van den Bergh O. Generalization of acquired somatic symptoms in response to odors: a pavlovian perspective on multiple chemical sensitivity. Psychosom Med. 2000;62:751-9.

90. Dantoft TM, Elberling J, Brix S, Szecsi PB, Vesterhauge S, Skovbjerg S. An elevated pro-inflammatory cytokine profile in multiple chemical sensitivity. Psychoneuroendocrinology. 2014;40:140-50. https://doi.org/10.1016/j. psyneuen.2013.11.012.

91. Inoue K. The function of microglia through purinergic receptors: neuropathic pain and cytokine release. Pharmacol Ther. 2006;109:210-26.

92. Lively S, Schlichter LC. Microglia responses to pro-inflammatory stimuli (LPS, IFN $y+T N F a$ ) and reprogramming by resolving cytokines (IL-4, IL-10). Front Cell Neurosci. 2018;12:215. https://doi.org/10.3389/fncel.2018.00215.

93. Réus GZ, Fries GR, Stertz L, Badawy M, Passos IC, Barichello T, Kapczinski F, Quevedo J. The role of inflammation and microglial activation in the pathophysiology of psychiatric disorders. Neuroscience. 2015;300:141-54.

94. Wang YL, Han QQ, Gong WQ, Pan DH, Wang LZ, Hu W, Yang M, Li B, Yu J, Liu Q. Microglial activation mediates chronic mild stress-induced depressiveand anxiety-like behavior in adult rats. J Neuroinflammation. 2018;15(1):21. https://doi.org/10.1186/s12974-018-1054-3.

95. Frank MG, Baratta MV, Sprunger DB, Watkins LR, Mair SF. Microglia serve as a neuroimmune substrate for stress-induced potentiation of CNS proinflammatory cytokine responses. Brain Behav Immun. 2006;21:47-59.

96. Sugama S, Fujita M, Hashimoto M, Conti B. Stress induced morphological microglial activation in the rodent brain: involvement of interleukin-18. Neuroscience. 2007;146:1388-99.

97. Clausen AN, Francisco AJ, Thelen J, Bruce J, Martin LE, McDowd J, Simmons WK, Aupperle RL. PTSD and cognitive symptoms relate to inhibition-related prefrontal activation and functional connectivity. Depress Anxiety. 2017;34:427-36.

98. Holmes SE, Scheinost D, Finnema SJ, Naganawa M, Davis MT, DellaGioia N Nabulsi N, Matuskey D, Angarita GA, Pietrzak RH, Duman RS, Sanacora G, Krystal JH, Carson RE, Esterlis I. Lower synaptic density is associated with depression severity and network alterations. Nat Commun. 2019;10(1):1529. https://doi.org/10.1038/s41467-019-09562-7.

99. Nordin S. Central sensitization as a possible underlying mechanism in idiopathic environmental intolerance attributed to chemicals. In: Abstract book and presentation in 31st International Congress on Occupational Health, SS-0473; 2015.
100. Bijlsma N, Cohen MM. Expert clinician's perspectives on environmental medicine and toxicant assessment in clinical practice. Environ Health Prev Med. 2018;23:19. https://doi.org/10.1186/s12199-018-0709-0.

101. Azuma K, Uchiyama I, Kunugita N. Factors affecting self-reported chemical intolerance: a five-year follow-up study in Japan. J Psychosom Res. 2019;118:1-8.

102. Apkarian AV, Bushnell MC, Treede RD, Zubieta JK. Human brain mechanisms of pain perception and regulation in health and disease. Eur J Pain. 2005;9:463-84.

103. Eek F, Karlson B, Osterberg K, Ostergren PO. Factors associated with prospective development of environmental annoyance. J Psychosom Res. 2010;69:9-15.

104. Skovbjerg S, Christensen KB, Ebstrup JF, Linneberg A, Zachariae R, Elberling $J$. Negative affect is associated with development and persistence of chemical intolerance: a prospective population-based study. J Psychosom Res. 2015;78:509-14.

105. Azuma K, Ohyama M, Azuma E, Nakajima T. Background factors of chemical intolerance and parent-child relationships. Environ Health Prev Med. 2018; 23:52. https://doi.org/10.1186/s12199-018-0743-y.

\section{Publisher's Note}

Springer Nature remains neutral with regard to jurisdictional claims in published maps and institutional affiliations.
Ready to submit your research? Choose BMC and benefit from:

- fast, convenient online submission

- thorough peer review by experienced researchers in your field

- rapid publication on acceptance

- support for research data, including large and complex data types

- gold Open Access which fosters wider collaboration and increased citations

- maximum visibility for your research: over $100 \mathrm{M}$ website views per year

At BMC, research is always in progress.

Learn more biomedcentral.com/submissions 